\title{
Balanced scorecard adoption in healthcare
}

\section{Renato Lopes da Costa*}

Business Research Unit - BRU-IUL,

ISCTE - Instituto Universitário de Lisboa,

Lisbon, Portugal

Email: renatojlc@gmail.com

*Corresponding author

\section{Leandro Pereira}

BRU - Business Research Unit,

ISCTE - Instituto Universitário de Lisboa,

WINNING LAB,

Lisbon, Portugal

Email: leandro.pereira@iscte-iul.pt

\section{Álvaro Dias}

Universidade Lusófona de Humanidades e Tecnologias,

ISCTE - Instituto Universitário de Lisboa,

Lisbon, Portugal

Email: alvaro.dias1@gmail.com

\section{Rui Gonçalves}

\section{LABEST,}

Instituto Piaget,

Avenida Jorge Peixinho, n. ${ }^{\circ} 30$ — Quinta da Arreinela,

2805-059 Almada, Portugal

Email: ruiahgoncalves@gmail.com

\section{Carlos H. Jerónimo}

WINNING LAB,

Alameda das Linhas de Torres, N. ${ }^{\circ} 152$,

Escritório 14 1750-149, Lisboa, Portugal

Email: carlos.jeronimo@winning.pt

\begin{abstract}
The health sector is gaining more and more space in the market. The offer of health services, of different specialties, has been increasing exponentially in the last decades. However, professionals in the field have little knowledge of management and many do not know how to use this knowledge in favour of their establishment. The lack of adequate management in health services can lead to not only financial losses, but the delivery of low-quality services can have serious consequences for the health of the client/patient. The
\end{abstract}


objective of the present study was to understand the potential of balanced scorecard adoption in health institutions. The research was based on secondary data of hundreds of articles about the adoption of this standard is health sector. The results showed that the balanced scorecard is an effective method to apply in public and private health sector.

Keywords: health service; balanced scorecard; BSC; health management; standard adoption.

Reference to this paper should be made as follows: Lopes da Costa, R., Pereira, L., Dias, A., Gonçalves, R. and Jerónimo, C.H. (2022) 'Balanced scorecard adoption in healthcare', Int. J. Electronic Healthcare, Vol. 12, No. 1, pp. $22-40$.

Biographical notes: Renato Lopes da Costa holds a $\mathrm{PhD}$ in General Management, Strategy and Business Development by ISCTE (Portugal) and has articles published in several specialised journals in the East, the USA, Canada, Africa, South America and Portugal. He is currently a researcher and member of BRU-UNIDE and Professor at INDEG where he holds the post of Director of the MScBA (Master in Business Administration) and guides students in the development of Masters and $\mathrm{PhD}$ theses. He teaches business strategy modules in executive and post-graduate master's degrees. Since 2013, he has also accumulated teaching duties as an Invited Professor at the Military Academy where he teaches the knowledge management.

Leandro Pereira is a Professor of Strategy and Management at ISCTE Business School. He holds a PhD in Project Management. He is also the CEO and Founder of WINNING Scientific Management. He is also the former President of Business Case Institute, PMI Portugal Chapter and a Training Specialist of the Court of Auditors. As CEO, he receives from best team's leaders the award of Best Team Leader and CEO of Portugal in 2017 in Portugal. He is also a PMP from PMI and ROI certified. As a researcher, he published more than 50 scientific publications and ten books. As a student, he received the Best Student Award from University of Minho. He is an international expert in strategic management, project management, benefits realisation management, and problem solving.

Álvaro Dias is a Professor of Strategy at Instituto Superior de Gestão and ISCTE-IUL, both in Lisbon, Portugal. He got his $\mathrm{PhD}$ in Management from the Universidad de Extremadura, Spain, after an MBA in International Business. He has over 24 years of teaching experience. He has had several visiting positions in different countries and institutions including Brazil, Angola, Spain, Poland and Finland. He regularly teaches in English, Portuguese, and Spanish at undergraduate, Masters and doctorate levels, as well as in executive programs. He has produced extensive research in the field of tourism and management, including books, book chapters, papers in scientific journals and conference proceedings, case studies, and working papers.

Rui Gonçalves holds a $\mathrm{PhD}$ in Management from the Instituto Superior de Economia e Gestão, with research in information systems for operational risk management, Master's in Statistics and Information Management from the NOVA Information Management School (NOVA IMS), with research in the area of intelligent agents, and degree in Business Management from the International University. He is currently a Guest Assistant Professor at NOVA IMS and works as the Manager in the Business Expertise division at SAS Portugal. In recent years, he has coordinated the areas of operational risk, compliance, fraud, audit and money laundering. 
Carlos H. Jerónimo is a Portuguese Professor of Strategic Management and Project Management at ISCTE in Lisbon. His research covers a wide range of areas: portfolio management, organisational behaviour, public sector modernisation, and citizen driven theories. However, he is best known in academia and requested by several European companies in the contribution of the evolution and reinvention of business models. He has a degree in Computer Science and Telematics from University de Aveiro, PhD in Business Administration and Management from ISCTE, founding partner of Winning Scientific Management and has divided his career between management consulting and academia. He is a mentor, guest speaker in several management events. He was also the Vice President of PMI Portugal from 2015 to 2018.

\section{Introduction}

In the last decades, the growth of the market has led companies from different branches to turn their attention to business management. Management is nothing more than the planning of actions to achieve a certain objective. This concept is based on four bases: planning, organisation, leadership and control. Since then, several theories about business management, strategy management, quality management, etc. have arisen. This way, Moisés Filho et al. (2010, p.16) proposes a definition for strategic management applied to the health area,

Strategic management is to develop, through an innovative and creative approach, a competitive strategy that ensures the success of the organisation in current businesses, while building the essential competencies necessary for business success tomorrow. Knowing and analysing the past, taking it as a source of our information and knowledge, but having a permanent look to the future, a space in which the actions defined today will materialise and cause consequences

Generally, there is an existing successful model in a particular country (or company) and tries to apply it. However, this adaptation may prove to be a failure if the local culture, the company's mission and its reality are very different from the reality of the model in question (GVF, 2020; Garcia and Riveira, 2013). In addition, these concepts become dynamic not only because of the differences between organisations, but also as the economy evolve, along with changes in the way of thinking (and consuming) (Garcia and Riveira, 2013). With the evolution and greater access to information, the customer is increasingly demanding and aware of their rights in relation to the services provided (Santos et al., 2019).

Currently, it is understood that for the success of an organisation, it is necessary to observe each gear involved. Since then, the performance analysis of a company has stopped having the financial objective as a major objective and has expanded its business vision, as it became clear that other important factors needed to change for the greater success of the enterprise (Hasan and Chyi, 2017).

In the health sector, it was no different. The market is increasingly competitive and the consumer of health services is more demanding. It is not enough to offer the service; the client wants quality, hospitality, confidence in the structure and team of the place where he is investing his greatest good, health. In this case, in addition to all the issues involved in the management of any company, the product delivered by this sector is healthcare, often the cure. So, when service has flaws in its management, it can lead to 
errors that, literally, cost the customer's life. Thus, identifying weaknesses and establishing effective strategies is essential for client health and for maintaining the sustainable health sector enterprise (Moisés Filho et al., 2010).

For that, some methods have been applied in hospitals, clinics and in health establishments in general. Most of these methods use one or two factors as the main focus point in managing a service, such as crisis management, financial management, etc. (Garcia and Riveira, 2013). However, there is a method that considers each sector of a company in the performance analysis with promising results, or balanced scorecard (BSC).

Kaplan and Norton (1992) first proposed the performance management system called BSC. It is an instrument used to assess performance and assist in the development of new management strategies for a given company (Malbašić and Marimon, 2019). This system is widely used worldwide, being a reference in Asia (Hasan and Chyi, 2017). It is not a fixed business management model, it has already been modified due to new demands and the trend is that it is always evolving.

The BSC has become an essential component for strategic planning and management systems (Hasan and Chyi, 2017). BSC is often used in a personalised way. According to the intended objective, one or more of its categories is prioritised. For making an assessment with a broad view of the business, BSC is also widely used by non-profit companies (Malbašić and Marimon, 2019).

Due to its wide coverage, the BSC has proved to be a great tool for the management of health service institutions (public and private). Thus, it is important to assess what the literature has shown about the implementation of this system in the health area so that it can establish which are the strengths and weaknesses of this methodology.

So, the main goal of this research is to analyse through a systematic literature review the effects of implementing the BSC Method in health services, and have the follow specific objectives:

1 Analyse the use of the BSC method to evaluate the performance of public health services.

2 Analyse the use of the BSC method to evaluate the performance of private health services.

3 Analyse the effects of implementing the BSC method to correct strategy management in public health services.

4 Analyse the effects of implementing the BSC method to correct strategy management in private health services.

This article is divided into four sections: Section 2 - theoretical framework: this chapter will present the theoretical basis that justifies the theme chosen by the present work; Section 3 - methods: the methods followed for the development of the literature review carried out in this research will be described; Section 4 - results: this topic demonstrates the results of the research, the results of the searches as well as the analysis of the data found in the literature. This chapter will be divided into four topics: research results, BSC in health services management, BSC in public health services and BSC in private health services; and Section 5 - conclusion: The conclusions, contributions of the studies to the knowledge area and to the working professionals and the limitations of the study will be presented. 


\section{Theoretical framework}

\subsection{Health management}

According to the World Health Organization (WHO, 2010), it is extremely important to promote, protect and restore health in order to achieve the population's contingencies. However, the population's dissatisfaction with the health sector (public and private) shows that these expectations have not been reached (Lorenzetti et al., 2014). Besides that, unlike most other sectors, in the health area, dissatisfaction and/or lack of quality in the surrender of a service in many cases is related to clinical outcome and may result in irreparable damage to the client's health (Burns et al., 2013). In addition to these factors, currently the clients (patients) of health services have greater access to information and more care options that end up increasing the demand for the sector (Catuogno et al., 2017).

The failures observed in health services, in most cases, are related to the fact that these institutions have focused for many years only on healthcare itself, without the view of the institution as an organisation that needs management in order to function efficiently (Moisés Filho et al., 2010).

For Lorenzetti et al. (2014, p.418), health management is "knowledge applied in the management of the complex of health organizations, involving the management of networks, public health spheres, hospitals, laboratories, clinics and other health service institutions". These authors also add that, [...] the observation that health management is still anchored in traditional methods and strategies, derived from the classical theory of administration, is recurrent. In addition, that building new forms of management in the health area, based on participation, cooperative and interdisciplinary practices where workers and users act as active subjects, remains a challenge [Lorenzetti et al., (2014), p.418].

One of the major management problems in the health area is the lack of training of the professionals in question in the management area, this concern and the search for adequate training to manage this type of business has been growing in recent years. However, the administration of health services is still closely linked to old conservative concepts (Lorenzetti et al. 2014; Kfoury and Lizote, 2020). Owners of clinics and medical offices still make basic mistakes in running their businesses due to lack of knowledge and preparation. As the demand for a differentiated and higher quality service has been growing in parallel with competition in the market, the necessity for innovation in management systems so that the health institution remains sustainable is increasingly greater (Kfoury and Lizote, 2020).

For this reason, currently, the sector seeks to renew itself through the implementation of quality management systems, strategy management, crisis management and performance assessments. The focus of health establishments became highly successful companies. So, adapting solutions to the sector has seemed appropriate so far (Garcia and Riveira, 2013; Santos et al., 2019; Kfoury and Lizote, 2020). Among several options of management and planning system, considering that the product sold is the health and well-being of the client, it was found that strategic planning should aim to provide an overview of the institution, with full harmony between those involved in the organisation, from finance to HR, from internal customer processes, etc. (Taichman and Parkinson, 2012). 
Some of the methods observed for quality control and evaluation and strategic planning are: National Accreditation Organisation (NAO), Joint Commission International (JCI), sistema strengths, weaknesses, opportunities, threats (SWOT), e $B S C$, which we will focus on this systematic review (Lorenzetti et al., 2014; Kfoury and Lizote, 2020).

\subsection{Balanced scorecard}

The BSC method was developed after understanding that a company's performance analysis goes beyond the financial sector (Abreu, 2016; Santos et al., 2019). For almost 30 years, the BSC has been the most discussed method that aims to transform strategic objectives into a set of measurable and tangible measures of performance. The balanced term refers to balance, which in this case would be the balance between financial and non-financial factors, internal and external processes, short-and long-term performance goals (Vitzec et al., 2019).

For the strategy management to be elaborated in a more reliable way, it is necessary that all sectors undergo an assessment to identify strengths and demands that need to be improved. That is, this model was born with the need to obtain a management instrument that was not based only on financial indicators, relating the entire organisational strategy and reconciling financial measures with non-financial measures (customers, internal processes, resources and infrastructure), the that would lead to an improvement in organisational performance (Abreu, 2016).

Initially, the BSC was composed of only four perspectives, which were criticised for not covering sufficient factors for a complete analysis of performance management. However, those responsible for introducing the BSC clarified that the proposed method was just a model that should be adapted to the reality of each company for its best implementation and results (Kaplan and Norton, 1996). The term balanced refers to balance be it between the perspectives proposed by the methods, the intended objectives, financial and organisational, as well as between the defined paths and the goals established to achieve success (Santos et al., 2019).

The main perspectives of the current BSC model are:

1 Financial - evaluates how much the organisational strategy influences the promotion of better financial results.

2 Customer - includes efficiency in delivering the product to the customer, quality management and customer satisfaction. Summarising this perspective, it keeps its focus on four factors, quality, time, service and performance.

3 Internal process - refers to the paths and goals established to achieve the performance objectives set by the company.

4 Learning and growth - involves training the team and updating information and systems that will add value to the business.

Some companies incorporate two more perspectives, which are risk management and social management. These two perspectives are related to the implementation of risk reduction, prevention, and relationship with the community, respectively.

Because it is based on several different perspectives, the BSC is able to identify in which areas the company needs improvement and, from then on, propose performance 
strategies that are in fact efficient (Malbašić and Marimon, 2019). According to Hasan and Chyi, (2017, p.99) "Método BSC fornece mecanismo de controle bidirecional, completando o ciclo de controle de cima para baixo e de volta para o topo repetidamente".

The BSC has been successfully implemented in several sectors, among them; we can mention hospitals and health services (Malbašić and Marimon, 2019; Hasan and Chyi, 2017; Catuogno et al., 2017). This method is the only one that makes clear and direct links between different dimensions of performance for the evaluation of a complex system such as health services (Kaplan, 2020; Catuogno et al., 2017). Considering the health management issues mentioned in the previous item and understanding the overview provided by the BSC, it is consistent to think that this would be a method with great chances of success in the health sector (Kaplan, 2020; Hasan and Chyi, 2017).

Thus, it is important to evaluate, what recent literature has found about the implementation of BSC in health services, in order to understand and improve the health management system currently used.

\section{Methods}

This research was designed based on the protocol by Tranfield et al. (2003), which divides the elaboration of a systematic review in three stages (planning, conducting and dissemination), based on the The Cochrane collaboration's Cochrane reviewers' Handbook e The National Health Service Dissemination (Clarke and Oxman, 2001 as quoted in Tranfield et al., 2003). The review was conducted without defining previous hypotheses, expanding the possibilities and considering all the results found in the researched articles.

\subsection{Review questions}

The purpose of this literature review is to present data on the implementation of management system and analysis the BSC performance, in the health sector in the period between 2015 and 2020. As well as to point out possible strengths and weaknesses of this methodology for that sector. The research will also seek to point out differences in implementation in large and small health services (for example, hospitals and clinics, respectively). Therefore the study's review questions are:

a What are the benefits of implementing BSC in the health service?

b What are the weaknesses of the BSC system in the health sector?

c What are the differences in the implementation of the BSC in large companies in large and small institutions in the health area?

\subsection{Research identification}

The search for publications for this research used the following databases, Google Scholar, Scielo and Pubmed. Therewithal, research was carried out on the website of the following reference journals in the area: Business Administration Magazine - GVF, Academy of Management, Administration Magazine - USP and Contemporary 
Administration Magazine - Mackenzie. The key words to search were: management, health management, strategic management, performance analysis and BSC. All terms used to search for articles were searched in English and Portuguese.

\subsection{Selection of studies}

After crossing all terms in all databases used for the related research, 475 articles were found. Then, the screening was accomplished by checking the abstracts of the articles, leaving 38 studies that really contemplated the content of interest in the research. Publications of articles, publications in full of scientific events, dissertation and doctoral thesis published in the period of five years, from 2015 to 2020 were considered. After reading, ten were finally selected (Figure 1).

Figure 1 Article selection

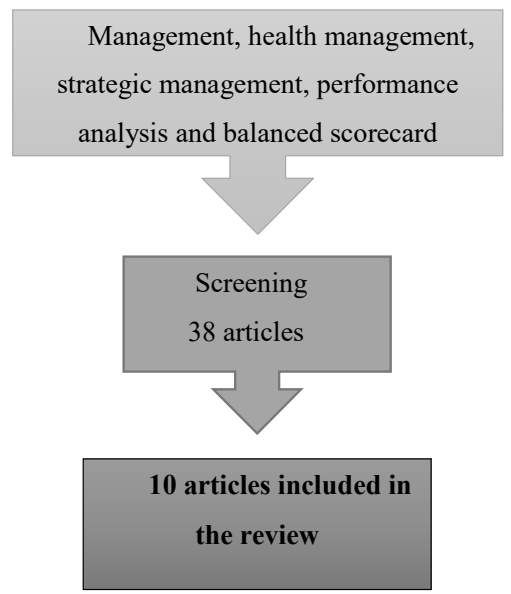

Source: Elaborated by authors

\subsection{Evaluation of the quality of studies}

The quality of the evaluation of the selected studies was carried out using the checklist proposed by Tranfield et al. (2003), in which studies with coherent methodology and reduction of possible biases and those studies whose content is considered relevant to answer the questions defined by the research are considered relevant.

\subsection{Data selection and synthesis}

To select and synthesise the data, original articles and literature reviews (including systematic reviews and meta-analyses) were initially considered. However, after reading the articles, we identified that the review articles selected articles that often considered criteria different from those established for this research. Therefore, it was defined that only original articles would be included for analysis of the present study. 


\section{Results}

After the selection and screening the publications resulting from the searches, 38 articles were within the inclusion criteria. Among these publications 30 were articles of systematic review and meta-analysis and ten were original articles (Figure 2).

Figure 2 Number of selected articles

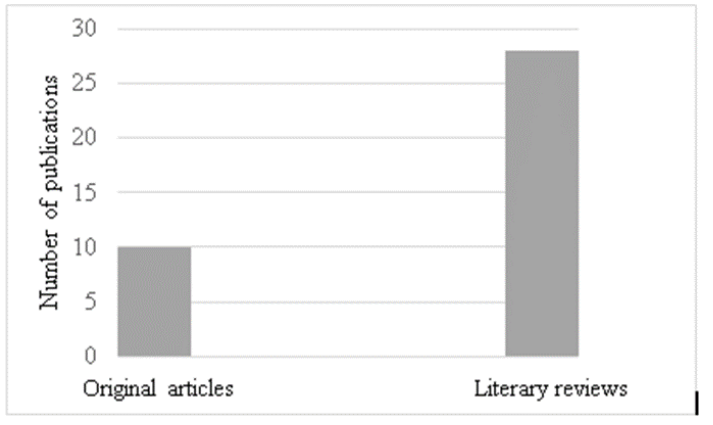

Source: Elaborated by authors

More than $50 \%$ of the publications were from Asian countries, as shown in Figure 3.

Figure 3 Number of publications by continent

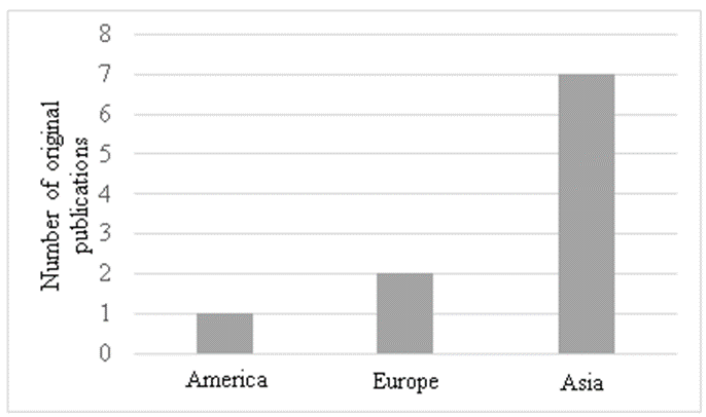

Source: Elaborated by authors

Table 1 presents a summary of the studies analysed. After reading the selected articles, they were considered original articles that used the BSC method as the focus of study. For this part of the research, review studies, systematic reviews or meta-analyses were not considered.

The division of the next items of the present work was defined according to the presentation of the evaluated articles. 
Table 1 Summary of studies analysed

\begin{tabular}{|c|c|c|}
\hline Author & Objective & Main results \\
\hline $\begin{array}{l}\text { Vitezic et al. } \\
\text { (2019) }\end{array}$ & $\begin{array}{l}\text { Analyse the DEA and BSC } \\
\text { models and propose an } \\
\text { integrated model. }\end{array}$ & $\begin{array}{l}\text { Inefficiency identified in two departments in } \\
\text { the health prevention sector and correction } \\
\text { with a focus on the BSC's learning and } \\
\text { innovation perspective. }\end{array}$ \\
\hline $\begin{array}{l}\text { Teklehaimanot } \\
\text { et al. (2016) }\end{array}$ & $\begin{array}{l}\text { Evaluate performance of } \\
\text { health services and } \\
\text { implement strategies to } \\
\text { improve service quality in } \\
\text { different regions of Ethiopia. }\end{array}$ & $\begin{array}{l}\text { At national level, deficiency in structure, } \\
\text { human resources, financial management of } \\
\text { the purchase of medicines, prevention of } \\
\text { infections, maternal, child and family health. } \\
\text { Regionally, the strengths and weaknesses of } \\
\text { performance were different, which } \\
\text { demonstrated a demand for a new } \\
\text { management strategy specific to each region. }\end{array}$ \\
\hline $\begin{array}{l}\text { Leksono et al. } \\
\text { (2019) }\end{array}$ & $\begin{array}{l}\text { Develop a performance } \\
\text { measurement model at health } \\
\text { area that takes into account } \\
\text { unattainable characteristics } \\
\text { and aspects of sustainability } \\
\text { that lead to customer/patient } \\
\text { satisfaction. }\end{array}$ & $\begin{array}{l}\text { Perspectives client and innovation, and } \\
\text { learning are the most important indicators for } \\
\text { the success of the performance strategy in } \\
\text { the health area. }\end{array}$ \\
\hline $\begin{array}{l}\text { Behrouzi and } \\
\text { Ma'aram } \\
(2019)\end{array}$ & $\begin{array}{l}\text { Establish efficient } \\
\text { performance measures for } \\
\text { Malaysian private hospitals. }\end{array}$ & $\begin{array}{l}\text { Forty four measures were considered } \\
\text { relevant, viable and accessible. In addition, } \\
\text { measures related to the 'customer' } \\
\text { perspective, with number of complaints, } \\
\text { rates of medical errors, number of patient } \\
\text { complaints and patient satisfaction, presented } \\
\text { higher scores than measures from the } \\
\text { financial perspective. }\end{array}$ \\
\hline $\begin{array}{l}\text { Catuogno et al. } \\
\text { (2017) }\end{array}$ & $\begin{array}{l}\text { Review, design and } \\
\text { implement measures of } \\
\text { multidimensional } \\
\text { performance analysis in an } \\
\text { Italian public research } \\
\text { hospital. }\end{array}$ & $\begin{array}{l}\text { The study demonstrates that the BSC can be } \\
\text { a personalised measure that considers } \\
\text { general and specific factors and that is why it } \\
\text { becomes very effective in this type of } \\
\text { institution. }\end{array}$ \\
\hline $\begin{array}{l}\text { Delen et al. } \\
(2020)\end{array}$ & $\begin{array}{l}\text { Evaluate and analyse } \\
\text { customer expectations in the } \\
\text { cosmetics sector. }\end{array}$ & $\begin{array}{l}\text { The BSC proved to be efficient in evaluating } \\
\text { customer expectations, identified that the } \\
\text { focus for this sector is the customer } \\
\text { perspective. }\end{array}$ \\
\hline $\begin{array}{l}\text { Dewi and } \\
\text { Santoso (2018) }\end{array}$ & $\begin{array}{l}\text { Evaluate through the BSC the } \\
\text { performance of the hospital } \\
\text { Tria Dipa (Indonesia), in } \\
\text { relation to hospitalisation of } \\
\text { patients. }\end{array}$ & $\begin{array}{l}\text { The results found that significant loss of } \\
\text { patients and dissatisfaction of the team, i.e., } \\
\text { low quality management that is directly } \\
\text { affecting the evaluated institution. The BSC } \\
\text { identified failures before they were } \\
\text { irreversible. }\end{array}$ \\
\hline $\begin{array}{l}\text { Gao et al. } \\
(2018)\end{array}$ & $\begin{array}{l}\text { Establish a system of } \\
\text { performance indicators in } \\
\text { hospitals in an } \\
\text { underdeveloped region in } \\
\text { China. }\end{array}$ & $\begin{array}{l}\text { Weaknesses and strengths were found in the } \\
\text { four perspectives. Furthermore, good non- } \\
\text { financial performance was not enough for the } \\
\text { success of management. }\end{array}$ \\
\hline
\end{tabular}

Source: Elaborated by authors 
Table 1 Summary of studies analysed (continued)

\begin{tabular}{lll}
\hline Author & \multicolumn{1}{c}{ Objective } & \multicolumn{1}{c}{ Main results } \\
\hline $\begin{array}{l}\text { Hatefi and } \\
\text { Haeri (2019) }\end{array}$ & $\begin{array}{l}\text { Evaluate the efficiency of } \\
\text { eight hospitals using the } \\
\text { combined performance } \\
\text { analysis model } \\
\text { BSC-fuzzy-DEA. }\end{array}$ & $\begin{array}{l}\text { Health institutions, whose objectives were } \\
\text { consistent with the indicators established } \\
\text { from the perspective of the BSC, were those } \\
\text { that showed the highest efficiency rates. }\end{array}$ \\
$\begin{array}{l}\text { Rahimi et al. } \\
(2018)\end{array}$ & $\begin{array}{l}\text { Organise key performance } \\
\text { indicators (KPIs) suitable for } \\
\text { evaluating the performance of } \\
\text { hospitals based on the BSC. }\end{array}$ & $\begin{array}{l}\text { The identification of key indicators was } \\
\text { efficient to guide the points that needed more } \\
\text { attention and with higher priority in the } \\
\text { health service in question. }\end{array}$ \\
\hline
\end{tabular}

Source: Elaborated by authors

\subsection{BSC and management in health services}

Management in health services, regardless of the magnitude of the service, aims to organise expenses, improve (or at least maintain) the quality of the service and expand its service capacity (Vitzec et al., 2019). These authors define that, "A gestão e o desempenho dos cuidados de saúde devem ser definidos como uma combinação apropriada de eficiência e eficácia" [Vitzec et al., (2019), p.200]. However, it is often difficult to define which parameters should be taken into account when defining a strategy management and among these factors, which in fact have greater relevance (Behrouzi and Ma'aram, 2019).

The BSC is a method that has been widely used in health services, because it promotes the improvement of the information management system, focuses on the relationship between qualitative and quantitative factors, the rapid checking of the implemented measures (Vitzec et al., 2019). With this method, it is possible to make a strategic mapping of performance dimensions, which helps to identify, organise and connect a series of indicators evenly (Teklehaimanot et al., 2016).

\subsubsection{BSC in public health management}

It is clear that the sustainability of a health service depends on the orchestrated action of several variables, such as quality of care, health knowledge and information, physical and human resources, adequate structure and equipment and strategic management in line with community participation (Teklehaimanot et al., 2016).

This way, a survey was conducted in a public hospital in Indonesia, which the authors used the BSC to assess the performance of the hospital's inpatient service between 2013 and 2015. Analysis of the financial perspective showed that, financially, the hospital it is able to maintain the financial level, but there has been a decline in efficiency, which is directly related to the management strategy established during these years. On the other hand, effectiveness indicators showed high indexes (Dewi and Santoso, 2018).

Regarding the client/patient perspective, it was observed in this public hospital in Indonesia that there was a drop in the number of patients. This shows that patient loyalty is not occurring, probably due to the low satisfaction rates of this client. The evaluation of the internal processes showed inconsistency in the reports, lack of organisation in the control of the balance sheets and inconsistency between the employees' capacity and the job description, another indication of the institution's deficient management (Dewi and 
Santoso, 2018). Finally, the analysis of learning and innovation showed that the employee retention rate is high; however the level of satisfaction is low. All this information is extremely important for the sustainability of the institution and was hidden behind an acceptable financial performance (Dewi and Santoso, 2018). The research helped to identify and correct strategy errors, before affecting the evaluated institution.

An analysis by 25 experts in public hospitals in China considered the BSC and its four perspectives and from them created nine indicators that they called second degree and 36 third degree indicators, in order to perform a tracking on the strategic performance of these located hospitals in an underdeveloped region in China. It was identified in the study that some hospitals, despite having high scores on financial indicators, have problems with the team. Many managers and few trained professionals. In contrast, other hospitals in the region had high rates of client perspective, but financial and internal processes with major failures (Gao et al., 2018). This study makes clear the importance of taking the exclusive focus on financial parameters and expanding the management focus to factors called non-financial.

A study that evaluated different performance strategy methods, in combination, in order to establish which indicators have greater weight in the definition of management strategies, found that the BSC's 'client' and 'innovation and learning' perspectives were the indicators with greater importance in the evaluation and definition of performance strategies in the health area (Leksono et al., 2019).

A survey conducted in Croatia evaluated the use of a combination of management methods, the data envelopment analysis (DEA) and the BSC, in a unit of the public health department. This combination of methods was called cause-effect, as the DEA was used to evaluate relative efficiency and with these results the objectives of the BSC's strategic map were defined (Vitzec et al., 2019). The authors state that the BSC is somewhat flawed in assessing the inefficiency of human and material resources, an error that could be corrected with the use of the BSC in combination with the DEA (Figure 2). From the combination of the two methods, it was possible to carry out the process completely, determining that the points of inefficiency of the service were concentrated in the sectors of health prevention and correcting through the adequacy of the BSC's learning and innovation perspectives.

Figure 4 Cause-effect model - DEABSC

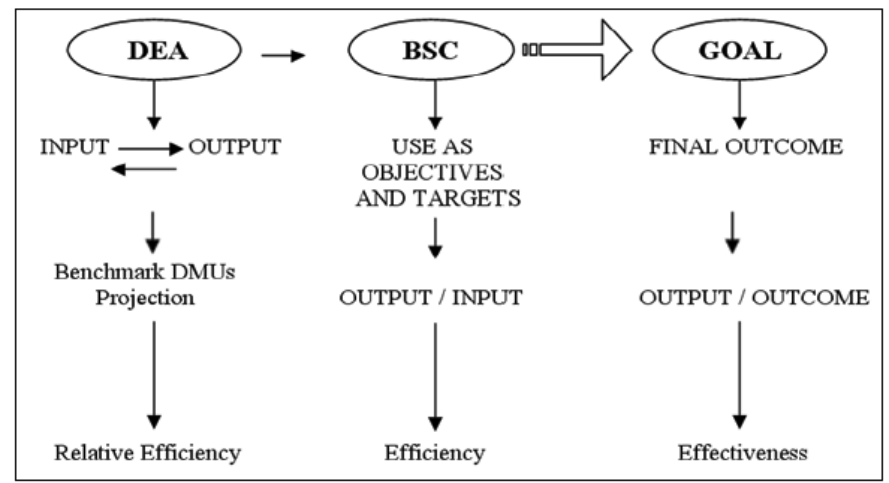

Source: Adapted de Vitzec et al. (2019) 
Table 2 BSC strategic map for Italian public hospital

\begin{tabular}{|c|c|c|c|}
\hline Perspective & Strategic objectives & Strategic directions & Performance indicators \\
\hline \multirow[t]{6}{*}{$\begin{array}{l}\text { Performance } \\
\text { indicators }\end{array}$} & $\begin{array}{l}\text { - Improve } \\
\text { accessibility }\end{array}$ & $\begin{array}{l}\text { - Promote care consistent } \\
\text { with stakeholder } \\
\text { expectations }\end{array}$ & - Home care services \\
\hline & - Increase loyalty & - Opportune care & - Departmental services \\
\hline & $\begin{array}{l}\text { - Increase patient } \\
\text { and employee } \\
\text { satisfaction }\end{array}$ & - Patient-centred care & $\begin{array}{l}\text { - Waiting time complaint } \\
\text { rate }\end{array}$ \\
\hline & \multirow{3}{*}{$\begin{array}{l}\text { - Improve the } \\
\text { sector's } \\
\text { reputation }\end{array}$} & - Equitable care & $\begin{array}{l}\text { - Relationship with } \\
\text { patients }\end{array}$ \\
\hline & & $\begin{array}{l}\text { - Equal opportunities for the } \\
\text { team }\end{array}$ & $\begin{array}{l}\text { - Professional } \\
\text { achievement }\end{array}$ \\
\hline & & - Stimulating environment & \\
\hline \multirow[t]{7}{*}{$\begin{array}{l}\text { Care } \\
\text { process }\end{array}$} & $\begin{array}{l}\text { - Achieve high } \\
\text { quality of care }\end{array}$ & $\begin{array}{l}\text { - Support for high quality } \\
\text { care delivery }\end{array}$ & - Mortality rates \\
\hline & $\begin{array}{l}\text { - Achieve high } \\
\text { productivity }\end{array}$ & - Promote clinical safety & $\begin{array}{l}\text { - Investment in home } \\
\text { care }\end{array}$ \\
\hline & \multirow[t]{5}{*}{$\begin{array}{l}\text { - Achieve internal } \\
\text { efficiency }\end{array}$} & $\begin{array}{l}\text { - Add value to the } \\
\text { department's services }\end{array}$ & - Investment in support \\
\hline & & - Innovation in cancer care & - Bed occupation \\
\hline & & $\begin{array}{l}\text { Promote home care as an } \\
\text { alternative to } \\
\text { hospitalisation }\end{array}$ & - Internalisation time \\
\hline & & $\begin{array}{l}\text { - Optimise support staff } \\
\text { productivity }\end{array}$ & - Repeated admissions \\
\hline & & $\begin{array}{l}\text { - Efficient delivery of } \\
\text { operations }\end{array}$ & - Transplants \\
\hline \multirow[t]{6}{*}{ Financial } & \multirow{6}{*}{$\begin{array}{l}\text { - Financial } \\
\text { sustainability for } \\
\text { the institution's } \\
\text { missions and } \\
\text { visions }\end{array}$} & $\begin{array}{l}\text { Achieve financial balance } \\
\text { through the effective } \\
\text { management of department } \\
\text { costs and revenues. }\end{array}$ & $\begin{array}{l}\text { - General value of } \\
\text { medicines }\end{array}$ \\
\hline & & - Respect budget constraints & - Number of patients \\
\hline & & - Increase hospital financing & - Number of admissions \\
\hline & & - Increase the patient base & - Average drug values \\
\hline & & - Optimise costs & - Cost containment \\
\hline & & - Capture new incomes & - Fundraising \\
\hline
\end{tabular}

Source: Adapted from Catuogno et al. (2017)

A study was accomplished in several regions of Ethiopia and, through the BSC; it was found that the performance in health management at a national level was low in relation to infrastructure, service provision, human resources and medication purchase management (Teklehaimanot et al., 2016). The survey also observed that the performance of certain departments was less than ideal, namely prevention and infections, maternal-child and family health. Nevertheless, the population's satisfaction with the 
service was high. However, the regional analysis showed that these indicators performed differently in each region (Teklehaimanot et al., 2016). The authors of this study established a colour panel that identified which strengths and weaknesses each region had. Besides that, points were highlighted that deserved attention, despite not having a low score (Teklehaimanot et al., 2016). Thus, it was possible to establish a specific and more efficient strategy for each region.

This way, another study found the effectiveness of BSC in the health sector when implementing this method in a public research hospital in Italy (Catuogno et al., 2017). These authors suggest that the parameters of the BSC be changed in relation to the order of importance and the client perspective move to the top of the list, as can be seen in the proposed strategic map of the BSC (Table 2).

Catuogno et al. (2017) concluded after the implementation of the BSC that, for a successful strategic performance, it is necessary to improve and bring closer the relationship between directors and medical staff, including nurses and other professionals involved. Moreover, define a scheme for collecting and updating the indicators established with frequent review and redirection of goals, as well as establishing new indicators when it is necessary.

\subsubsection{BSC private management}

The private health sector is an area with an extremely competitive market. The main objectives of this sector are to optimise costs aiming at greater financial return and greater customer satisfaction. However, in this case, customer satisfaction involves a very precious asset, your health. Moreover, the increase in the supply of health services makes it necessary for performance measures to be constantly evaluated and adapted to new demands (Behrouzi and Ma'aram, 2019).

A survey of 35 private hospitals in Malaysia used a questionnaire to identify performance measures that were viable and relevant. In this study, hospital directors and senior managers answered questions. The measures were defined from the four perspectives of the BSC and indicators used in other surveys (Behrouzi and Ma'aram, 2019). After analysing the results, it was found that the directors who answered the questions had at least three years of management experience and at least five years of experience in the health sector. Ten measures of financial performance were established, nine from the client/patient perspective, seven from internal processes and five from innovation and learning (Table 3). It was observed in this study that the measures related to the 'customer' perspective, with number of complaints, rates of medical errors, number of patient complaints and patient satisfaction, revealed higher scores than measures from the financial perspective. This fact demonstrates that in health services, non-financial indicators can have a great influence on the profit and general performance of these institutions (Behrouzi and Ma'aram, 2019).

Results similar to those observed by Behrouzi and Ma'aram (2019), were confirmed by Delen et al. (2020) when evaluating the implementation of the BSC in cosmetology services in Ukraine. These authors conducted a survey of the 13 main clinics in this specialty and found that the indicators referring to the BSC's client perspective showed greater significance, i.e., the criteria related to the diversification of services, service feedback and client/patient loyalty, were more influential in evaluating the performance of this type of service (Delen et al., 2020). The authors also observed that, for this sector, 
it is important to diversify the services in order to attend the expectations of the clients and follow the changes in the profile of the consumer market of the health service.

Table 3 Identification of BSC performance measures for private hospitals in Malaysia

\begin{tabular}{|c|c|}
\hline$B S C$ perspective & Relevant, feasible and accessible measures* \\
\hline \multirow[t]{9}{*}{ Financial } & Return over investment \\
\hline & Turnover rate assets cash flow \\
\hline & Average profit per hospital bed \\
\hline & Indebtedness index \\
\hline & Net profit margin \\
\hline & Cost per patient/day \\
\hline & Stock turnover rate \\
\hline & Return on net worth \\
\hline & Current reason \\
\hline \multirow[t]{10}{*}{ Client/patient } & Patient satisfaction index \\
\hline & Number of patient complaints \\
\hline & Average waiting time \\
\hline & Customer retention rate \\
\hline & Hospital beds per 1,000 people \\
\hline & Average length of hospital stay \\
\hline & Percentage of postoperative infections \\
\hline & Mortality rate of patients \\
\hline & Percentage of new customers \\
\hline & Percentage of cases transferred to other hospitals \\
\hline \multirow[t]{7}{*}{ Internal processes } & Employee satisfaction index \\
\hline & Employee retention rate \\
\hline & Employee absenteeism rate \\
\hline & Occupancy rate of 30 beds \\
\hline & Availability of 31 beds \\
\hline & Average length of stay \\
\hline & Medical error rate \\
\hline \multirow{5}{*}{$\begin{array}{l}\text { Innovation and } \\
\text { learning }\end{array}$} & Percentage of budget allocated to the acquisition of new technologies \\
\hline & Percentage of trained employees \\
\hline & Number of hours of training in improvement culture \\
\hline & Average hours of training per employee \\
\hline & Percentage of budget allocated to information technology \\
\hline
\end{tabular}

Note: *Measures with a score above 3 , according point established by the literature.

Source: Adapted from Behrouzi and Ma'aram, (2019)

In addition, as observed in public hospital management, private hospitals used the combination of BSC with other methodologies to identify and define performance management strategies. One study implemented the BSC combined with the fuzzy DEA in seven hospitals and a medical clinic in Iran, and demonstrated that these methods in 
combination were effective in identifying and defining best strategies for each hospital specifically. The analysis confirmed that the best performance and highest levels of efficiency were found in institutions where the indicators established from the perspective of the BSC were consistent with the establishment's mission and vision. Even then, three hospitals and the medical clinic were the institutions with the best efficiency assessment (Hatefi and Haeri, 2019).

Finally, the studies presented in the present research were unanimous in relation to one point: in the management of health services, indicators related to the client (patient) have greater importance in the analysis of performance than the other factors. However, it is also clear that the factors involved in evaluating the management of health institutions cannot be analysed separately, as they are influenced by each other. For this reason, Rahimi et al. (2018) sought to identify which are the key indicators for the management of health services. It was found that in relation to the client perspective (assessed as an effect parameter), the key indicators were the satisfaction rate and the complaints rate of patients. These indicators, if they score low, can have negative effects on hospital income. However, it is possible to establish strategies that will raise these items through services of higher quality with care attention focused mainly on the patient. However, from the perspective of learning and innovation, it was identified as a cause parameter. This perspective proved to be directly related to the institution's organisational performance. The authors suggest that by providing better working conditions, training and continuing education for the team, medical errors are decreased, team satisfaction is improved and, consequently, customer service (Rahimi et al., 2018).

\section{Conclusions}

It is clear in the literature that health service management is a growing and constantly evolving area, especially in recent decades. The significance of looking at the health service with an enterprise is increasingly essential for the sustainability of the establishment, both financially and for the overall success and better delivery of such an important product, health.

The lack of knowledge about management, management strategies and performance analysis by health professionals is a negative point for the development of the health sector market. This area has been growing and the competition has been increasing, in addition to this, the client/patient is increasingly informed and demanding better quality of the health services offered.

Therefore, in order to approach excellence in the services offered by the sector, as well as optimise expenses and provide sustainable growth for these enterprises, the search for the most efficient management strategy is essential. For that, it is necessary to take the focus only on financial parameters and expand the view considering non-financial parameters. Accordingly, the BSC method has been used by health services in countries around the world. Its single implementation or in combination with other methodologies is effective in identifying strengths and weaknesses and in defining performance management strategies. From this review, it became clear that the identification of specific indicators based on the four perspectives of the BSC, increased the chances of business success. Studies have also shown that the main parameter to be considered in health services is the customer. Establishing a balance between the various indicators and the objectives of the institution is the key to the sustainability of the health service. 
Although many studies have evaluated the use of BSC in large health services, there are still few studies in small establishments, such as medical clinics. Thus, given how the benefits presented by the implementation of the BSC in health services, it makes us suggest, at least in part, that this method would also be very effective in smaller services.

The founders of the BSC method make clear the significance of the evolution of the method, with possible inclusion or improvement of the evaluation of previously established parameters. Thereby, more studies evaluating the method, comparing it to other strategies and proposing innovations in this performance analysis would be interesting and would increase more value to the area still under explored in the health sector.

Many researchers are involved in evaluating efficient management methods for healthcare institutions. However, this is one of the first studies to evaluate, in the same work, the benefits of implementing the BSC in public and private institutions.

From the present work, it was possible to verify the effectiveness of the BSC method in health services with different missions, visions, objectives and regardless of the complexity of the health service. The analysis of the implementation of the method, whether to diagnose performance or to correct the management strategy, made the importance of management for the health area even more evident.

Beyond that, the results showed that the client is the most important parameter to be considered when choosing management strategies for the success and sustainability of the health institution. Furthermore, other non-financial parameters were of great importance for improving performance in these establishments.

Like most sectors and people around the world, the present work was somewhat limited due to the COVID-19 pandemic. Initially, the proposal of the study was to accomplish the systematic review and in addition to the field research with the implementation of the BSC in a medical and physiotherapy clinic.

However, with the pandemic, as a doctor and active on the front line, the implementation of the second stage of the project became unfeasible. In addition, the restriction and the new protocols implemented by the government due to this very critical moment, ended up leading us to the decision to keep only the review as the focus of study. Thus, we would be able to present quality work despite the aforementioned unexpected conditions.

Another limiting point of the studies was the lack of work in small health institutions, most of the studies were accomplished in large institutions, in hospitals. There is a gap in knowledge and, consequently, the suggestion for studies in the future to evaluate these institutions.

\section{References}

Behrouzi, F. and Ma'aram, A. (2019) 'Identification and ranking of specific balanced scorecard performance measures for hospitals: a case study of private hospitals in the Klang Valley area, Malaysia', Int. J. Health Plann. Mgmt., Vol. 2019, No. 4, pp.1-13.

Burns, M., Manning, H., Stone, A. and Knott, J. (2013) The Costumer Experience Index, Forrester Research, Cambridge, MA.

Catuogno, S., Arena, C., Saggese, S. and Sarto, F. (2017) 'Balanced performance measurement in research hospitals: the participative case study of a haematology department', BMC Health Services Research, Vol. 17, No. 522, pp.1-11. 
Clarke, M. and Oxman, A.D. (Eds.): (2001) Cochrane Reviewers' Handbook 4.1.4. updated October, The Cochrane Library, Oxford.

Delen, D., Dorokhov, O., Dorokhova, L., Dinçer, H. and Yuksel, S. (2020) 'Balanced scorecard-based analysis of customer expectations for cosmetology services: a hybrid decision modeling approach', Journal of Management Analytics, Vol. 7, No. 4, pp.1-33.

Dewi, N.F. and Santoso, R.K. (2018) 'The performance analysis of inpatient installation at Tria Dipa hospital with balanced scorecard, 2013-2015', KnE Social Sciences, pp.1566-1583.

Gao, H. Chen, H., Feng, J., Qin, X., Wang, X., Liang, L. et al. (2018) 'Balanced scorecard-based performance evaluation of Chinese county hospitals in underdeveloped áreas', Journal of International Medical Research, Vol. 46, No. 5, pp.1947-1962.

Garcia, J. and Riveira, D. (2013) 'Critical success factors for Kaizen implementation in manufacturing industries in Mexico (2013)', Int. J. Adv. Manuf. Technol., Vol. 68, No. 1, pp.537-545.

Getúlio Vargas Foundation (GVF) (2020) Qualidade e acreditação em saúde, GVF, 76.

Hasan, R.U. and Chyi, T.M (2017) 'Practical application of balanced scorecard - a literature review', Journal of Strategy and Performance Management, Vol. 5, No. 3, pp.87-103.

Hatefi, S.M. and Haeri, A. (2019) 'Evaluation of hospital performance using a combined model of balanced scorecard and fuzzy data envelopment analysis', J. Health Man and Info, Vol. 6, No. 2, pp.66-76.

Kaplan, R.S. (2020) 'Using the balanced scorecard for successful health care M\&A integration', NEJM Catalyst Innovations in Care Delivery, pp.1-8.

Kaplan, R.S. and Norton, D.P. (1992) 'The balanced score card - measures that drive performance', Harvard Business Review, Vol. 70, No. 4, pp.71-79.

Kaplan, R.S. and Norton, D.P. (1996) The Balanced Scorecard: Translating Strategy into Action, Harvard Business School Press, Boston, MA.

Kfoury, T. and Lizote, S.A. (2020) 'Impacto do capital intelectual no desempenho e no desempenho gerencial de consultórios e clínicas', Congresso UFSC de Controladoria e Finanças, Florianópolis, SC, Brasil, Setembro, p.10.

Leksono, E.B., Suparno, S. and Vanany, I. (2019) 'Integration of a balanced scorecard, DEMATEL, and ANP for measuring the performance of a sustainable healthcare supply chain', Sustaintability, Vol. 11, No. 13, pp.1-18.

Lorenzetti, J., Lanzoni, G.M.M., Assuiti, L.F.C., Pires, D.E.P. and Ramos, R.F S. (2014) 'Gestão em saúde no Brasil: Diálogo com gestores públicos e privados', Texto, Contexto Enferm, Vol. 23, No. 2, pp.417-25.

Malbašić, I. and Marimon, F. (2019) 'A simplified balanced. balanced scorecard', European Accounting and Management Review, Vol. 5, No. 2, pp.38-60.

Moisés Filho, J., Kestelman, H.N., Becker Junior, L.C. and Torres, M.C.S. (2010) Planejamento e gestão estratégica em organizações de saúde, GVF, Rio de Janeiro, RJ.

Rahimi, H., Bahmaei, J., Shojaei, P., Kavosi, Z. and Khavasi, M. (2018) 'Developing a strategy map to improve public hospitals performance with balanced scorecard and DEMATEL approach', Shiraz E-Med J., Vol. 19, No. 7, p.e64056.

Santos, E.F., Catânio, A.R. and Pizzo, J.C.M. (2019) 'Análise das modificações do BSC a partir de uma revisão sistemática da literatura de periódicos nacionais', XXVI Congresso brasileiro de custos-Curitiba, PR, Brasil, Novembro p.26 [online] https://anaiscbc.emnuvens.com.br/ anais/article/viewFile/4592/4610 (accessed June 2020).

Taichman, R.S. and Parkinson, J.W. (2012) 'where is leadership training being taught in U.S. dental schools?', Journal of Dental Education, Vol. 76, No. 6, pp.713-720.

Teklehaimanot, H.D. Teklehaimanot, A., Tedella, A.A. and Abdella, M. (2016) 'Use of balanced scorecard methodology for performance measurement of the health extension program in Ethiopia', Am. J. Trop. Med. Hyg., Vol. 94, No. 5, pp.1157-1169. 
Tranfield, D., Denyer, D. and Smart, P. (2003) 'Towards a methodology for developing evidence-informed management knowledge by means of systematic review', British Journal of Management, Vol. 14, No. 3, pp.207-222.

Vitzec, N., Cankar, S.S. and Linsak, Z. (2019) 'Effectiveness measurement using DEA \& BSC methods in public health services', The NISPAcee Journal of PublicAdministration and Policy, Vol. 12, No. 1, pp.199-216.

World Health Organization (WHO) Health Systems Financing: The Path to Universal Coverage, WHO, Genebra (CH) [online] https://www.who.int/ whr/2010/10_summary_en.pdf (accessed June 2020). 